Research Article

\title{
Intracervical Lidocaine Block is more Effective for Pain Management of Curettage in Incomplete Abortion
}

\author{
Blok Intraservikal dengan Lidokain lebih Efektif untuk Penanganan Nyeri \\ pada Tindakan Kuretase Abortus Inkomplit
}

\author{
Oktovianus Saranga, Eddy Hartono, Isharyah Sunarno \\ Department of Obstetrics and Gynecology \\ Faculty of Medicine University of Hasanuddin/ \\ Dr. Wahidin Sudiro Husodo Hospital \\ Makassar
}

\begin{abstract}
Objective: To compare the effects of Intra cervical and paracervical block with $1 \%$ lidocaine for pain management in curettage of incomplete abortion.

Method: This study is a prospective study with Randomized Control Trial approach. The samples were 52 pregnant women with gestational age of less than 20 weeks, which diagnosed as having an incomplete abortion and a procedure using any local anesthetic technique. T test was used to calculate the mean VAS score and standard deviation for each group. Fisher Exact test was used to assess the relationship between variable characteristics and the local anesthetic technique.
\end{abstract}

Result: The use of local anesthesia using intra cervical block technique for pain management in incomplete abortion with curettage proved to be more effective in lowering degree of pain than paracervical block techniques.

Conclusion: Intracervical block technique as a local anesthetic technique is simpler and relatively safer than paracervical block. This technique can be used extensively in Department of Obstetrics and Gynecology Medical Faculty, Hasanuddin University for pain management in curettage.

[Indones J Obstet Gynecol 2014; 2-1: 13-17]

Keywords: pain, Intracervical anesthesia, paracervical anesthesia, Visual Analogue Scale (VAS)

\begin{abstract}
Abstrak
Tujuan: Untuk membandingkani efek intraservikal dan paraservikal blok dengan lidokain 1\% untuk penanganan nyeri pada tindakan kuretase abortus inkomplit.

Metode: Penelitian ini merupakan suatu penelitian prospektif dengan pendekatan Randomized Control Trial. Sampel penelitian adalah 52 perempuan hamil dengan usia kehamilan kurang dari 20 minggu dihitung dari hari pertama haid terakhir (HPHT) yang didiagnosis sebagai abortus inkomplit pada setiap teknik anestesi lokal. Digunakan uji $t$ untuk menghitung nilai rerata skor VAS dan standar deviasi pada tiap kelompok. Untuk menilai hubungan karakteristik dengan teknik anestesi lokal digunakan uji statistik Fisher Exact.
\end{abstract}

Hasil: Penggunaan anestesi lokal untuk penanganan nyeri pada tindakan kuretase abortus inkomplit dengan teknik intraservikal blok terbukti lebih efektif daripada teknik paraservikal blok yang dibuktikan dengan derajat nyeri yang lebih rendah.

Kesimpulan: Teknik blok intraservikal merupakan teknik anastesi lokal yang lebih sederhana dan aman dibandingkan blok para servikal. Teknik ini bisa digunakan secara luas di Departemen Obstetri dan Ginekologi Fakultas Kedokteran Universitas Hasanuddin, Makassar, dalam penatalaksanaan nyeri pada prosedur kuretase.

[Maj Obstet Ginekol Indones 2014; 2-1: 13-17]

Kata kunci: anestesi intraservikal, anestesi paraservikal, nyeri, Visual Analogue Scale (VAS)

Correspondence: Oktovianus Saranga. Jalan Taman Telkomas, Jl. Perumtel II no. 11, Makassar.

Telephone/mobile: 081342462969. Email: ot2o_obginjuli08@yahoo.co.id

\section{INTRODUCTION}

Based on a survey conducted in 1995 in 57 countries of the world, the global incidence of abortion was about 45.5 million. Survey conducted by Utomo et al in 2000 estimated two million abortions was occurred in Indonesia. Based on data from the Health Department of South Sulawesi province, the abortion incidence in 2010 was 3476 cases. $^{1}$

Dilatation and curettage is one of the most common procedures in obstetrics and gynecology de- partment. $^{2}$

Curettage was closely related to the pain that caused by vagina, cervix and uterus stretching. Pain management in curettage could be done by using general anesthesia, local anesthesia with nitrous oxide combination, intravenous sedation combined with local anesthesia, and local anesthesia with or without additional oral medications. ${ }^{3}$

Local anesthetics have been shown to be safer than general anesthesia for pain management in suction curettage. ${ }^{4}$ 
Local anesthetics have been known as pain treatment in curettage by the method of anesthetic of paracervical local injection (paracervical block). Local anesthetic techniques are simpler in the pain management of curettage with a local anesthetic of Intracervical injection techniques (Intracervical block). Unlike the paracervical block, which is a peripheral nerve block, the Intracervical block is an anesthetic infiltration through the stretch of tissue, thereby causing mechanical disruption of nerve impulses. $^{2}$

VAS values were significantly lower in Intracervical block group than paracervical block group. This is because the paracervical block technique is a peripheral nerve block in which the precision of injection site will determine the degree of the effectiveness in the resulting pain while the Intracervical block technique is an anesthetic infiltration that does not require precision of injection site. ${ }^{2,5}$

In the Department of Obstetrics and Gynecology, Faculty of Medicine Hasanuddin University, there was still no data on the effect of Intracervical block for curettage in incomplete abortion. Under these conditions, it is necessary to do a study to assess the effects of Intracervical block with 1\% lidocaine for pain management in curettage for abortion incomplete.

\section{METHOD}

This study was conducted in several teaching hospitals of Medical Faculty Hasanuddin University, Makassar. This study was a prospective study using the Randomized Control Trial approach. The study population was all the pregnant women who come to the hospital and was diagnosed as having an incomplete abortion after anamnesis, physical examination, and supporting examination and planned to have a curettage performed.

Samples taken in the study were pregnant women with gestational age less than 20 weeks counted from the first day of last menstrual period (LMP), who were diagnosed as an incomplete abortion and had signed an informed consent to have a curettage performed and approval of local anesthesia using paracervical or Intracervical lidocaine. The sample size for each study group is 52 people.

Pregnant women who have incomplete abortion, $>50 \mathrm{Kg}$ weight, not using analgesics, sedatives as well as having complications with sedatives were randomly selected to achieve the required sample size.

Anamneses about obstetric history using a questionnaire as well as a general physical and obstetric examination were conducted. Patients were divided into 2 groups. Group A was given lidocaine Intracervical block and group B was given lidocaine paracervical block. Patients were given $800 \mathrm{mg}$ oral tablet Ibuprofen before curettage. Each patient group was told that injecting these drugs do have a relationship with pain in curettage.

Data are grouped according to the purpose of research and analysis conducted using statistics programs. T test was used to calculate the mean of VAS score and standard deviation for each group. Fisher Exact test was used to assess the characteristics of the relationship with the local anesthetic technique.

\section{RESULTS}

Table 1 shows that both groups of the study can be considered homogeneous by age, education level, history of abortion, gravid and parturition, because the X2 test for differences in distribution based on variables showed no significant differences ( $p>0.05)$. Homogeneity of the two groups based on age, education level, history of abortion, Gravid and parturition can be seen in Table 1.

The results of independent $t$ test analysis between the two groups can be seen in Table 2. VAS values during curettage ranged from 3.0 to 3.8 with a VAS score in group Intracervical block technique ranged between 3.0 - 3.5, whereas in the group of paracervical block techniques ranged from 3.5 to 38.

Table 2 and Figure 1 showed that the results of independent $\mathrm{t}$ test analysis at all observation time ( $5^{\text {th }}$ minute, $10^{\text {th }}$ minute and $15^{\text {th }}$ minute), the VAS value of intracervical block technique group (3.27 $\pm 0.14)$ was significantly lower $(\mathrm{p}<0.05)$ than in paracervical block technique group $(3.65 \pm 0.10)$. The VAS score in both groups categorized into groups VAS1 $=3.0$ to 3.4 and group VAS2 $=3.5$ to 3.8, and the distributive comparison in both groups were tested with Fisher's Exact test at some time of observation. The result can be seen in Table 3 . 
Table 1. Distribution of Age, Education Level, History of Abortion, Gravid and Parturition in both Groups.

\begin{tabular}{|c|c|c|c|c|}
\hline \multirow{2}{*}{ Variable } & \multirow{2}{*}{ Category } & \multicolumn{2}{|c|}{ Group } & \multirow{2}{*}{$X^{2}$ test } \\
\hline & & Intracervical $(n=52)$ & Paraservical $(n=52)$ & \\
\hline & $20-29$ & 29 & 26 & \\
\hline \multirow[t]{2}{*}{ Age (Years) } & $30-39$ & 20 & 24 & $\mathrm{p}=0.695$ \\
\hline & $40-49$ & 3 & 2 & \\
\hline \multirow[t]{3}{*}{ Abortus } & Yes & 11 & 7 & $\mathrm{p}=0.300$ \\
\hline & No & 41 & 45 & \\
\hline & 1 & 14 & 14 & \\
\hline \multirow[t]{3}{*}{ Gravid } & 2 & 15 & 13 & $\mathrm{p}=0.377$ \\
\hline & $\geq 3$ & 23 & 25 & \\
\hline & 0 & 16 & 15 & \\
\hline \multirow[t]{2}{*}{ Partus } & 1 & 17 & 12 & $\mathrm{p}=0.650$ \\
\hline & $\geq 2$ & 19 & 25 & \\
\hline
\end{tabular}

Table 2. Comparison between the VAS Value Engineering and Engineering Intracervical Block Paracervical Block at Some Time Observations.

\begin{tabular}{lccc}
\hline \hline \multirow{2}{*}{ Observation Time } & \multicolumn{2}{c}{ Mean \pm SD nilai VAS } & Independent Sample t test \\
\cline { 2 - 4 } & Intracervical $(\mathbf{n = 5 2 )}$ & Paraservical $(\mathbf{n = 5 2})$ & $\mathrm{p}=0.000$ \\
\hline 5 minute & $3.27 \pm 0.14$ & $3.65 \pm 0.10$ & $\mathrm{p}=0.000$ \\
10 minute & $3.27 \pm 0.14$ & $3.65 \pm 0.10$ & $\mathrm{p}=0.000$ \\
15 minute & $3.27 \pm 0.14$ & $3.65 \pm 0.10$ & \\
\hline \hline
\end{tabular}

Table 3. Comparison of the Distribution of VAS Score between Intracervical Category and Paracervical at Some Time Observations.

\begin{tabular}{|c|c|c|c|c|}
\hline \multirow{2}{*}{ Observation Time } & \multirow{2}{*}{ Group } & \multicolumn{2}{|c|}{ VAS } & \multirow{2}{*}{ Fisher's Exact test } \\
\hline & & $3.0-3.4$ & $3.5-3.8$ & \\
\hline \multirow{2}{*}{5 Minute } & Intracervical $(n=52)$ & 47 & 5 & \multirow{2}{*}{$\mathrm{p}=0.000$} \\
\hline & Paraservical $(n=52)$ & 0 & 52 & \\
\hline \multirow[t]{2}{*}{10 Minute } & Intracervical $(\mathrm{n}=52)$ & 47 & 5 & \multirow{2}{*}{$\mathrm{p}=0.000$} \\
\hline & Paraservical $(n=52)$ & 0 & 52 & \\
\hline \multirow{2}{*}{15 Minute } & Intracervical $(\mathrm{n}=52)$ & 47 & 5 & \multirow{2}{*}{$\mathrm{p}=0.000$} \\
\hline & Paraservical $(n=52)$ & 0 & 52 & \\
\hline
\end{tabular}

From Table 3 it can be seen that there were differences in the distribution of categories of VAS values between the two groups at any observation time. Of 52 people, there are 47 people $(90.4 \%)$ felt pain in first $5^{\text {th }}$ minute who blocked by using Intracervical technique with the highest VAS was
3.4, and $5(9.6 \%)$ at the lowest category 3.5. In the group of paracervical block technique, all (100.0\%) VAS has lowest score, namely 3.5. Fisher's Exact test showed a significant difference $(\mathrm{p}<0.05)$. Differences in the distribution of VAS values were maintained (fixed) during the 15-minute intra-curettage observation. 


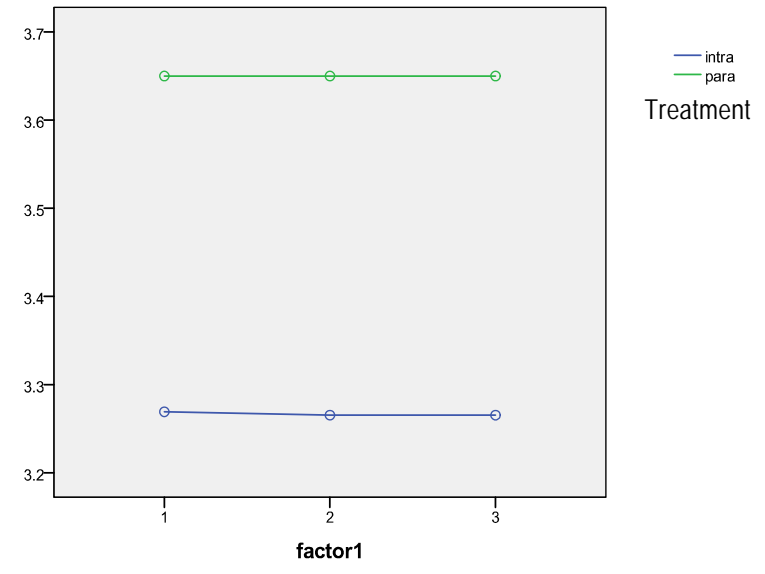

Figure 1. Comparison between the VAS value engineering and engineering Intracervical block paracervical block at some time observations.

\section{DISCUSSION}

This study found that the use of local anesthesia of Intracervical block technique for pain management in incomplete abortion with curettage proved to be more effective in lowering degree of pain than paracervical block techniques. In this study, we tried to introduce the local anesthetic technique that relatively new with its simpler application and its lower risk when compared with paracervical block techniques that have been known before. Through this study we tried to determine how the effects of Intracervical block technique compared with paracervical block technique in lowering the degree of pain in curettage of incomplete abortion.

In this study, the majority of samples were at the age of 20-29 years with history a gravid $>3$ and history of delivery of 2 and never got abortion (Table 1). A similar trend was found by Delvi et al who stated that in Indonesia, the incidence of abortion was most prevalent in the age of 20-29 years. ${ }^{6}$

Degree of pain to the two local anesthetic techniques in this study belongs to the mild pain with VAS score of less than 4. Based on observations, VAS value (Table 2) and its distribution (Table 3) at some time of observation were obtained significantly lower in the group of blocks Intracervical techniques than in group of paracervical block technique. This is because the technique of paracervical block is a peripheral nerve block technique in which the precision of injection site will deter- mine the degree of effectiveness in resulting pain while the technique of Intracervical block infiltration anesthesia does not require precision of injection site. ${ }^{2-5}$

Paracervical block techniques aims to block the ganglion and plexus Frankenhauser or uterovaginal plexus that supplies the uterus, and vagina. ${ }^{7,8}$ Paracervical block techniques vary in terms of injection site as well as the type and amount of anesthetic agent used. ${ }^{9}$ Due to the anatomical position of plexus Frankenhauser or uterovaginal plexus fibers which are mostly located in the cardinal ligament in the medial uterine artery with a small portion runs along the uterine arteries, therefore there was a risk the entry of an anesthetic substance into the blood vessel through the uterine artery during paracervical block. ${ }^{7}$ Additionally, anesthetic agent injected directly into the nerve will cause severe pain and result in nerve damage. The limitation of Intracervical block infiltration technique is large quantities of drugs to anesthetize a relatively small area is required.10

\section{CONCLUSION}

Intracervical block technique as a local anesthetic technique is simpler and relatively safer than paracervical block. This technique can be used extensively in Department of Obstetrics and Gynecology Medical Faculty, Hasanuddin University for pain management in curettage. Further research may need to assess its effect on other measures in the field of Obstetrics and Gynecology at the Medical Faculty of Hasanuddin University.

\section{REFERENCES}

1. Dinkes Sul-Sel Gambaran Kasus Obstetri dan Ginekologi di Makassar. Makassar; 2010.

2. Mankowski JL, K J, Thomas T, Nager Cw, Lukacz Es. Paracervival Compared With Intracervical Lidocaine for Suction Curettage. In: American College of Obstetricians and Gynecologists. New York: Lippincott Williams and Wilkins; 2009: 1052-57.

3. Lichtenberg CA. Pregnancy Loss Termination. In: General Gynecology. Mosby Elsevier; 2007: 225-56.

4. WHO (2003). Safe Abortion: Technical and Policy Guidance for Health Systems. Switzerland; 2003.

5. Morgentaler (1973). Report on 5641 Outpatient Abortions by Vacuum Suction Curettage. CMA J. 1973; 109: 1202-15.

6. Delvie B, Widyantoro, Silviane (2008). A Study of Knowledge, Attitudes and Understanding of Legal Professionals about Safe Abortion as a Women's Right. Available from: www.asap-asia.org.

7. Shoja Mm SA, Mirzayan N, Groat C, Watanabe K, Loukas M, 
Tubbs R (2013). Neuroanatomy of the Female Abdominopelvic Region: A Review With Application to Pelvic Pain Syndromes. Clin Anatomy, 2013: 26. Wiley Periodicals Inc. 2013: 66-76. Available from: www.wileyonlinelibrary.com

8. Cunningham Fg LK, Bloom Sl, Hauth Jc. Wenstrom Obstetrical Anaesthesia. In: Wliams Obstetrics. 22 ${ }^{\text {nd }}$ Ed. New York: Mc Graw Hill; 2005: 473-90.
9. Renner J, Nichols, Edelman Pain control in first trimester surgical abortion (Review). The Cochrane Library 2009, issue 2. Available from: www.thecochranelibrary.com

10. Brunton Ll PK, Blumenthal Dk, Buxton Lo. Local anesthetics. In: Manual of Pharmacology and Therapeutics. New York: Mc Graw Hill; 2008: 241-52. 